\title{
REGIONAL AIRPORTS' ENVIRONMENTAL MANAGEMENT: KEY MESSAGES FROM THE EVALUATION OF TEN EUROPEAN AIRPORTS
}

\author{
D.J. DIMITRIOU \& A.J. VOSKAKI \\ Department of Aerospace Science, School of Engineering, Cranfield University, UK.
}

\begin{abstract}
In a modern society, connectivity is the basis for economic competitiveness, social reform, regional development and cultural exchange. City airports serving mature markets have already expanded to meet existing and future demand and the challenge for the airport industry is now focused on the development of the secondary and regional airports to accommodate further air transport demand. Consequently, regional airports attract the interest of investors by providing new business opportunities. Although airports bring significant benefits to local and national economy, their contribution to environment disturbance in local and global scale is significant. As a result of the growing environmental sensitivity, airport environmental management is a crucial element of the aviation industry development. This is for reasons related to the control of community and nongovernmental organisations (NGOs) complaints on one hand, and to meet the regional and national targets set by the civil aviation and local authorities on the other hand. Especially for regional airports, the need to identify the environmental issues is essential, because their business development is directly linked to disturbance in the environment and to the local/national communities' level of tolerance. Although environmental management process is crucial to regional airport development, there is little research related to measuring the efficiency and the performance of their environmental management systems. Nevertheless, not many regional airports, especially those serving fewer than 5 million passengers, annually, have set specific targets for their environmental performance. This paper presents the results of the evaluation of 10 European regional airports' environmental plans. Conventional wisdom is to provide some key messages, in order to improve the planning and decision process in airport environment management, as well as highlight some recommendations for further research in the future. The key research finding is that the national legislation framework and resident's ethics along with the airport business factions (such as the management scheme, the location topology and the airport size) are essential elements strongly related to regional airport's environmental efficiency.
\end{abstract}

Keywords: airports sustainable development, environmental plan, environmental planning, regional airports.

\section{INTRODUCTION}

In the global society of the 21 st century air transport plays a significant role in supporting social and economic development by providing accessibility. Planners, economists and managers recognise that the aviation industry plays a key role in the globalisation of the economy, national/regional economic development and social affairs. The airport industry has experienced strong growth during the last 40 years, and International Civil Aviation Organisation (ICAO) estimates that worldwide aircraft departures and aircraft kilometre flown will increase at an average annual rate of $3.6 \%$ and $4.1 \%$, respectively, between 2005 and 2025. Despite the small decline in the air transport demand growth, because of the recent economic crisis, long-term forecasts indicate that air transport demand will continue to increase in both mature markets, such as those of the USA and Europe, as well as in developing markets, such as those of the East Asia and China [1].

Although the benefits of aviation growth are significant, the environmental implications of meeting the new demand are significant too. Increased public concern regarding the protection of the environment from the impacts of air transport has shown that an appropriate balance between the growth of air transport and environmental protection must be found. Opportunities to grow exist, only if environmental capacity could be increased. As a result, the development of existing environmental management plans and procedures is inevitable. 
This paper deals with the measures to control environment disturbance due to the growth of aviation traffic. The main concern of this research is to investigate the differences of the environmental plans that have been adopted by the airport industry, and propose the key issues towards a sustainable airport development. The research is focused on European regional airports, where the analysis of the existing environmental plans shows that country's legislation, location and airport's size play a significant role to airports' environmental protection performance.

The paper is organised in five sections. In the first section, the role of airports in regional development is briefly given. In the second section, the key issues of the environmental management system at airports are analysed. In the next section, the elements of the environmental plans of 10 European regional airports are presented, while in the following section, the key messages of the analysis of these environmental plans are given. Finally, the research conclusions and the references used can be found at the end of the paper.

\section{AIRPORTS AND REGIONAL DEVELOPMENT}

Airports bring significant social benefits and in many cases they are thought to be the single largest generator of economic activity in the regions they serve, as emphasised by Airports Council International (ACI) Europe [2]. Whilst important for economic growth, the strong and sustained growth of transport is anticipated to be accompanied by significant environmental impacts. It is well recognised that the benefits of aviation are significant, although aviation has also significant impact upon climate change and disturbance of the local environment, which can generate opposition to airport operations and act as a capacity constraint to aviation growth [3-5].

Air transport is essential to the development of regional and local economies, as it generates economic growth, makes possible the expansion of the world trade, broadens people's leisure and cultural experiences, provides a wide choice of holiday destinations around the world, delivers emergency and humanitarian aid anywhere on earth, and provides access to remote areas. Besides that, airports provide economic prosperity to the region they serve, through direct and indirect jobs and other commercial development. Planners and urban policy-makers have long been concerned about the growth of air transports traffic and they recognise that airport location and its access system are issues that impact significantly the urban development and the local economy.

Major transport infrastructures such as airports, have substantial effects on cities' urban development because of their impact on local traffic, employment, economy and environment. The volume of air traffic is growing according to the trend of the aviation industry, leading airports to invest in new infrastructure to increase capacity. Therefore, air traffic accommodation along with surface traffic to and from the airport is related directly to airport accessibility and constitutes a significant part of the problem of urban development and land use planning.

Although airports carry out the businesses' and people's aspirations and needs, they have a negative impact on the environment and on the communities around them. Environmental impacts such as air pollution, noise, water and soil pollution, biodiversity loss can arise from the operation and development of airports. Therefore, the key question in the debate between airport managers and environmentalists is when the social and economic benefits of an airport to a region overbalance the disturbance on the environment and the human health [6,7]. The answer to this question is not a simple one and in many cases is not clear either, mainly because the estimations of the environmental impacts in surrounding communities and the regional urban activities transformations are based on assumptions that usually do not reflect what really happens.

Especially in Europe, any cost-benefit analysis of airport development is focused on business and management scenarios to keep the balance between the benefits from airport activities and the total cost (including the externalities) for the life cycle of the airport. However, the debate about the 
external cost and the impacts of environmental disturbance provides much opposition between stakeholders and NGOs on one side and airport authorities and business associations on the other.

Therefore, the management of the environmental disturbance is a critical issue towards airport development. The impacts at a regional level are always the first point of interest on the local level, but, also, the climate change and carbon control attract the interest at a national and international level. The global environmental sensitivity affects significantly the development of regional airports and leads to significant constrain to any future expansion.

\section{KEY ISSUES ON AIRPORTS' ENVIRONMENTAL ASSESSMENT}

In Europe, the need to encourage a more sustainable policy is well recognised. The High Level Group report on Networks for Peace and Development [8] devotes just three paragraphs (pp. 26-27) to the 'environmental dimension', which is treated in the most general of terms. The Group highlights 'the need to pay a special attention to environmental sustainability at the stage of project definition and analysis as well as when implementing the horizontal priorities'.

Recently, ACI Europe $[9,32]$ has committed to a landmark environmental resolution, as a further indication of how they wish to mitigate impacts on climate change. Also, the environmental sustainability of aviation in tourism destinations is discussed by many researchers, where the critical role of the Strategic Environmental Assessment (SEA) in future development of airports is highlighted [10].

On a global scale, the greenhouse gases (carbon dioxide, oxides of nitrogen and water vapour) emitted firstly from aircraft engines into the atmosphere and secondly from airports various activities make a significant and growing contribution to global warming and climate change. Worldwide aviation seems to be one of the most rapidly growing sources of $\mathrm{CO}_{2}$ emissions and recent studies have shown that the total influence of aviation on climate is greater than that has been suggested, reaching about $4.7 \%$ of the total anthropogenic change [10-12].

On a local level, acoustic airport capacity represents the main limit to their expansion, especially in regional airports. Noise seems to be one of the most significant causes of community reaction related to airports' operations. It has been recognised that air transport industry will develop sustainable if it could meet the increasing demand, while at the same time, constrain or reduce the number of people exposed to unacceptable levels of nuisance from aircraft noise [4, 10]. It is noteworthy that, a recent survey of European airports indicated that approximately two-thirds are already subject to noise restrictions, or have their operations constrained by noise related issues and that this figure could increase up to $80 \%$ in the next 5-10 years [3].

In addition, airports disturb the environment in many other ways, such as the consumption of natural resources, land use and impacts on biodiversity, microclimate and natural ecosystems located near them, which may face significant changes due to the airport operations [13].

\subsection{Noise}

The most significant local impact is the disturbance caused by aircraft noise in communities surrounding airports. This can make some destinations less attractive and generate opposition amongst local residents which can lead to constraints to the operations and growth of those airports [4].

Nowadays, many European airports are likely to be seriously constrained by environmental factors due to them being located close to inhabited areas. According to the environmental noise directive 2002/49/EC specific measures and initiatives should be implemented in order to reduce the environmental noise. This has forced airports' operators to prepare strategic noise maps and action plans, 
adopt a series of measures in order to reduce and mitigate noise pollution and inform the public about environmental noise. Some of them are listed below:

1. Preparation and implementation of airport's Noise Action plan, supported by noise indicators and strategic noise mapping. Day-evening-night level of noise $\mathrm{L}_{\text {den }}$ and night-time $\mathrm{L}_{\text {night }}$ noise indicators are defined by the directive's proposed formulas. Noise maps are produced through a modelling process and identify areas exposed to different levels of noise. Using the contour areas the population affected can be measured [14-16].

2. Air traffic management. Departing and arriving aircrafts are required to stay within defined corridors so as to affect as few people as possible.

3. Operating restrictions and limits, especially at night. For example a limit to the allowed night movements could be set.

4. Differential charging in order to encourage the use of quieter aircraft.

5. Monitoring of noise level in order to revise the existing plan and assess measures for further noise reduction.

6. Construction of anti-noise barriers to protect the local communities.

7. Registration of noise complaints by local communities.

\subsection{Emissions}

Airport activities produce an enormous amount of various pollutants that influence the air quality of the area and contribute to climate change. For the purpose of this paper only emissions of $\mathrm{CO}_{2}$, major contributor to global warming, will be taken into consideration. Airports, in order to be sustainable, must calculate their carbon emissions of all their activities. Recently, ACI Europe [17] has launched the 'Airport Carbon Accreditation program', according to which, airports that will join the scheme must commit to reducing $\mathrm{CO}_{2}$ emissions within their direct control, as an effort to improve their environmental behaviour. Airports, in order to reach carbon neutrality, follow a series of measures; a few of them are mentioned below [18]:

1. Energy-efficient design of the airport building and infrastructure.

2. Reduction of required energy.

3. Promote public transport.

4. Use energy from renewable sources.

5. Participate in an emission trading scheme and purchase carbon credits to cover emissions.

6. Force airline industry to reduce $\mathrm{CO}_{2}$ emissions.

7. Use hybrid or electric vehicles.

\subsection{Water}

The various activities of the airport require enormous amount of water. Considering the increasing pressure to reduce water consumption and conserve the water resources, airports must manage their activities in order to consume less water and to protect the surface and ground water resources. Airports, in order to protect and conserve water resources, follow a series of measures, a few of them are mentioned below:

1. Reduce water consumption at the airport site.

2. Reuse water, after treatment (wastewater treatment plant and sewage treatment plant) in toilet facilities or for irrigation purposes.

3. Use rainwater in toilet facilities or for irrigation purposes.

4. Protect the groundwater from pollution. 
5. Monitor water consumption.

6. Monitor the quality of surface and groundwater.

\subsection{Waste}

The various activities of the airport generate a lot of waste. According to 'The Polluter Pays' principle, airports must develop a complete waste management system that includes, amongst other, waste separation at source and recycling. Airports waste management, follow a series of measures, a few of them are mentioned below:

1. Source separation and recycling on airport site.

2. Waste minimisation and charges for waste.

3. Reuse equipments and materials where possible.

4. Promote the usage of products that are renewable and have the least environmental impact.

\section{KEY ELEMENTS OF TEN EUROPEAN REGIONAL AIRPORTS' ENVIRONMENTAL PLANS}

\subsection{Regional airports' environmental plan}

The need to monitor airport performance has been recognised in the literature from the early 1990s. Especially for regional airports the need to identify the environmental issues is essential, because their business development is directly linked to disturbance in environment and local/national communities' level of tolerance. Surprisingly, in contrast to many other industries many airports still only assess their performance by using simple traffic, operational and financial measures. This happens especially to regional airports for several reasons, among which two are the most important:

1. the nature of the airport business, where many airports are still under the government protection accepting purely financial and productivity objectives; and

2. there does not exist a widely accepted business practice or system for measuring airport operational performance.

It is noteworthy that while many publications present airport operational and management performance [19-21] there is a little research on comparing environmental measures efficiency between airports and other industries [22]. The difficulties on defining environmental capacity may provide some difficulties to evaluating performance of environmental management systems; however, the need for the industry to put forward potential measures, best practices and evidence of calibration towards sustainability should provide the framework for more focused research on the future.

This paper presents the research results related to key components of the environmental plans that have been adopted in 10 European regional airports. Key issue of this research is to investigate the differences and common practices applied in environmental strategies and systems. A detailed analysis of airports' environmental plans showed the following categories:

1. noise;

2. climate change;

3. air quality;

4. water;

5. waste; and

6. ecosystems.

According to the above categories, Tables 1 and 2 illustrate the information included in environmental plans of 10 European airports. 


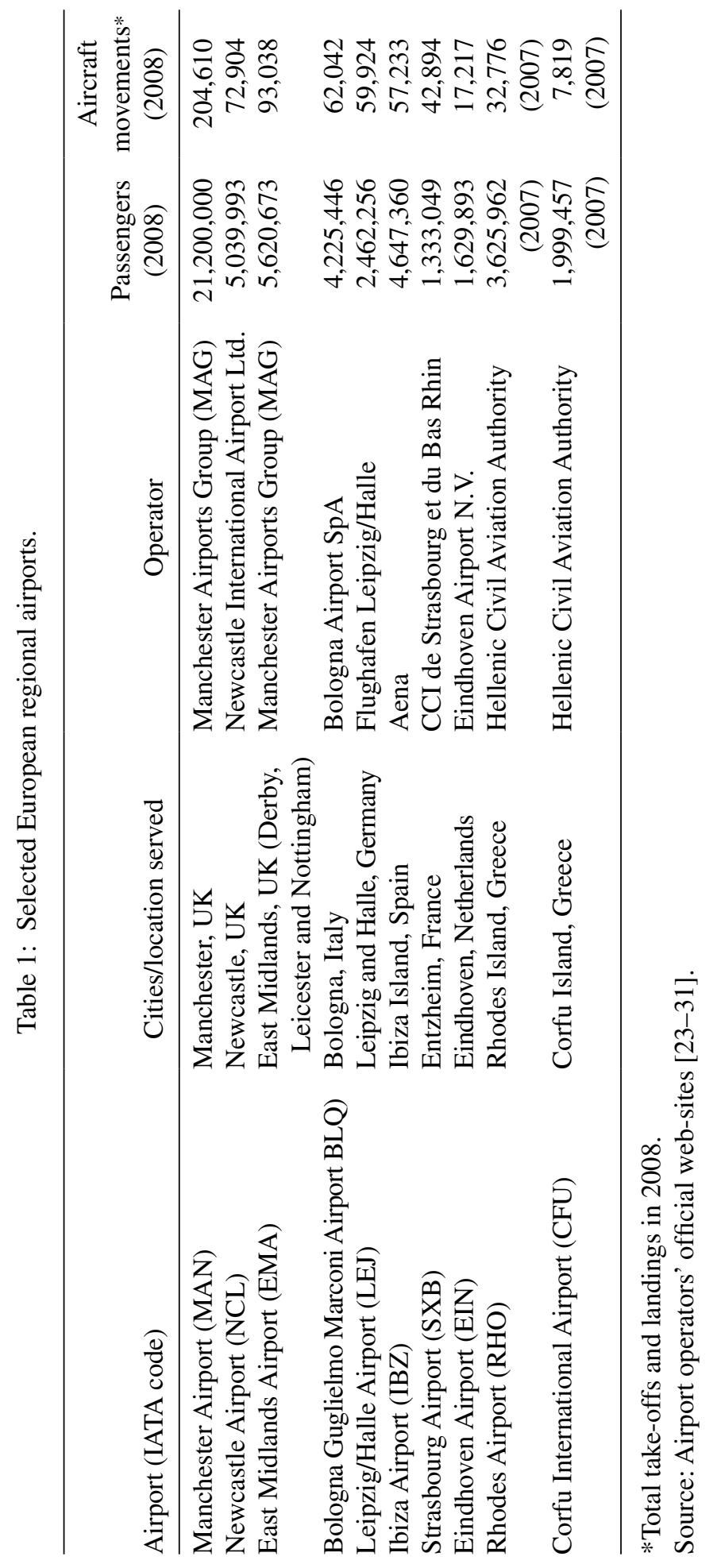




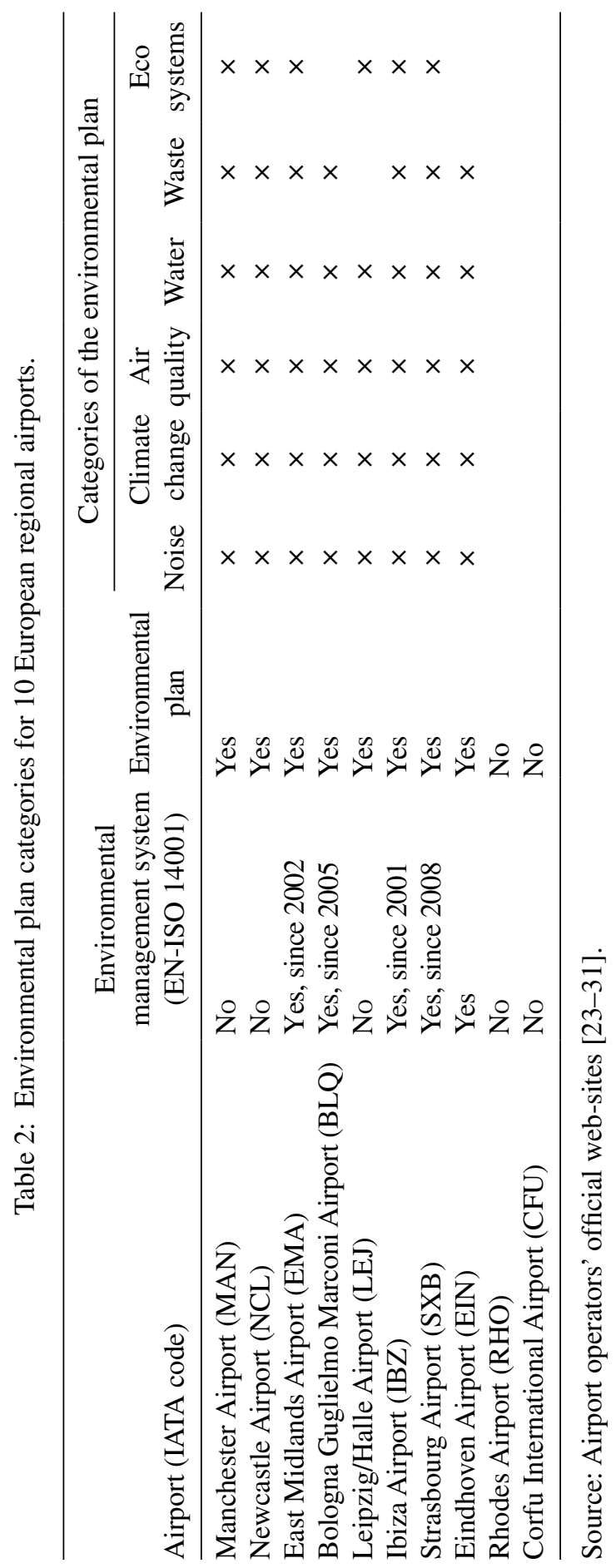


4.2 Content of the main categories of environmental plans

The most significant measures adopted, by the 10 European regional airports are presented in Tables 3-8.

Table 3: Measures taken, regarding noise, for 10 European regional airports.

\begin{tabular}{lcccccccccc}
\hline & \multicolumn{10}{c}{ Airports } \\
\cline { 2 - 9 } Measures regarding noise & MAN & NCL & EMA & BLQ & LEJ & IBZ & SXB & EIN & RHO CFU \\
\hline Noise action plan or other noise & $\times$ & $\times$ & $\times$ & & $\times$ & $\times$ & $\times$ & $\times$ & \\
$\quad$ protection program & & & & & & & & & \\
Aircraft noise impact reporting & $\times$ & $\times$ & $\times$ & $\times$ & & $\times$ & $\times$ & & \\
Noise monitoring & $\times$ & $\times$ & $\times$ & $\times$ & $\times$ & & $\times$ & $\times$ & \\
Operating restrictions & $\times$ & $\times$ & $\times$ & $\times$ & $\times$ & & $\times$ & $\times$ & \\
Air traffic management & $\times$ & $\times$ & $\times$ & $\times$ & $\times$ & & $\times$ & $\times$ & \\
Land use planning & $\times$ & $\times$ & $\times$ & & & & & & \\
Noise barriers or other special & $\times$ & & & $\times$ & $\times$ & $\times$ & $\times$ & & \\
$\quad$ infrastructure to buildings & & & & & & & & & \\
Noise fee policy & $\times$ & & $\times$ & & $\times$ & & $\times$ & & \\
Registration of noise complaints & $\times$ & $\times$ & $\times$ & & & & & $\times$ \\
\hline
\end{tabular}

Source: Airport operators' official web-sites [23-31].

Table 4: Measures taken, regarding climate change, for 10 European regional airports.

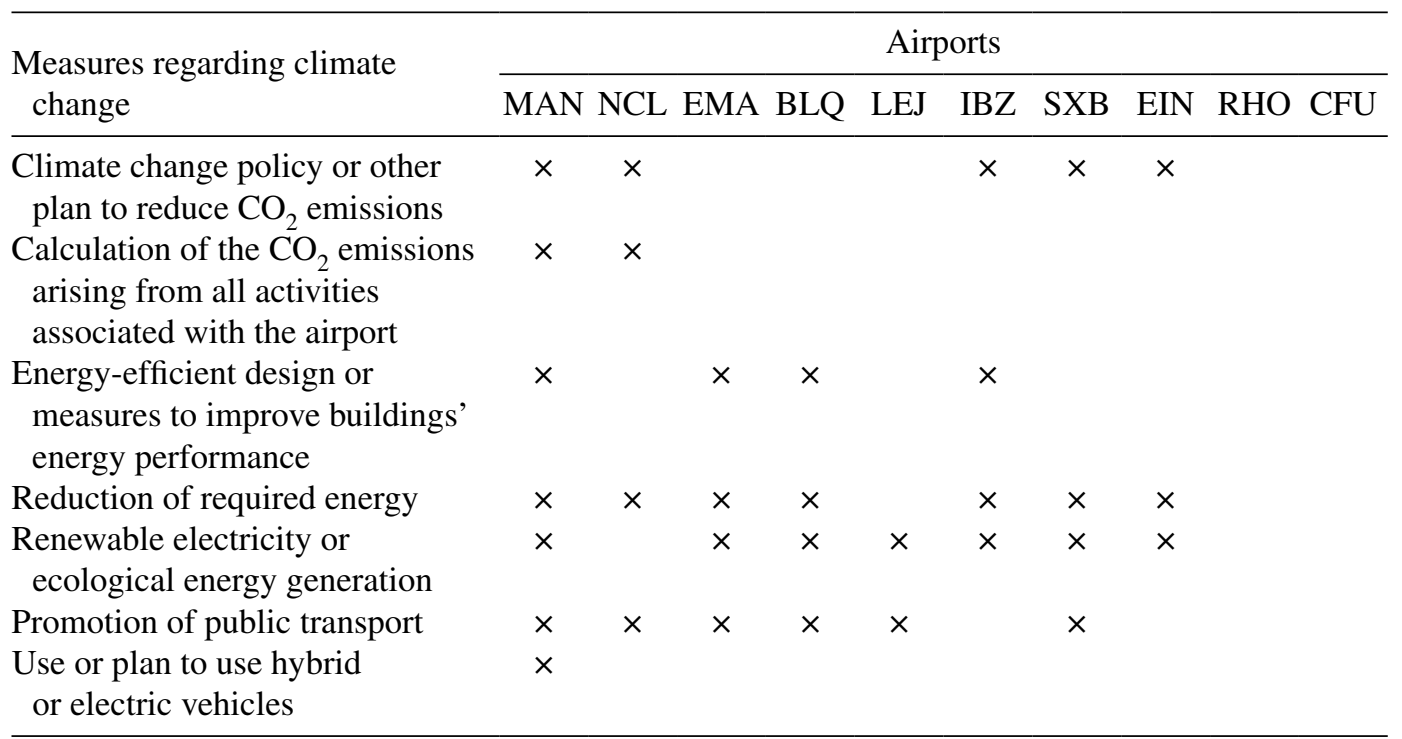

Source: Airport operators' official web-sites [23-31]. 
Table 5: Measures taken, regarding air quality, for 10 European regional airports.

\begin{tabular}{lllllllllll}
\hline & \multicolumn{10}{c}{ Airports } \\
\cline { 2 - 9 } Measures regarding air quality & MAN NCL & EMA & BLQ & LEJ & IBZ & SXB & EIN RHO CFU \\
\hline Air quality monitoring & $\times$ & $\times$ & $\times$ & $\times$ & & $\times$ & $\times$ & & \\
Air quality reporting/modelling & $\times$ & $\times$ & $\times$ & $\times$ & & $\times$ & $\times$ & & \\
Air quality management (reduction & $\times$ & $\times$ & $\times$ & $\times$ & & $\times$ & $\times$ & $\times$ \\
of air quality related emissions) & & & & & & & & \\
\hline
\end{tabular}

Source: Airport operators' official web-sites [23-31].

Table 6: Measures taken, regarding water, for 10 European regional airports.

\begin{tabular}{|c|c|c|c|c|c|c|c|c|c|}
\hline \multirow[b]{2}{*}{ Measures regarding water } & \multicolumn{9}{|c|}{ Airports } \\
\hline & MAN & NCL & EMA & BLQ & LEJ & IBZ & SXB & EIN & RHO CFU \\
\hline $\begin{array}{l}\text { Monitor the quality of surface } \\
\text { and/or groundwater }\end{array}$ & $x$ & $\times$ & $x$ & $\times$ & $x$ & $x$ & $x$ & & \\
\hline Management of the water runoffs & $\times$ & $x$ & $\times$ & $x$ & $x$ & & $x$ & & \\
\hline Monitor water consumption & $x$ & & & & & & & & \\
\hline $\begin{array}{l}\text { Water conservation program } \\
\text { or water saving policy }\end{array}$ & $x$ & & & $x$ & & $\times$ & $\times$ & & \\
\hline $\begin{array}{l}\text { Use or plan to use rainwater } \\
\text { or grey water after treatment } \\
\text { (where possible) }\end{array}$ & $x$ & & & & & $x$ & & $x$ & \\
\hline $\begin{array}{l}\text { Water saving devices, leak } \\
\text { detection program }\end{array}$ & $\times$ & & & & & $\times$ & & & \\
\hline Wastewater treatment & & & & & $\times$ & $\times$ & $\times$ & & \\
\hline
\end{tabular}

Source: Airport operators' official web-sites [23-31].

Table 7: Measures taken, regarding waste management, for 10 European regional airports.

\begin{tabular}{|c|c|c|c|c|c|c|c|c|c|}
\hline \multirow{2}{*}{$\begin{array}{l}\text { Measures regarding waste } \\
\text { management }\end{array}$} & \multicolumn{9}{|c|}{ Airports } \\
\hline & MAN & NCL & EMA & BLQ & LEJ & IBZ & SXB & EIN & RHO CFU \\
\hline Recycling & $\times$ & $\times$ & $\times$ & $\times$ & & $x$ & $\times$ & $\times$ & \\
\hline Waste and recycling facilities & $\times$ & & $x$ & & & & & $x$ & \\
\hline $\begin{array}{l}\text { Charges for contamination } \\
\text { of recycling containers }\end{array}$ & $x$ & & & & & & & & \\
\hline Calculation of the generated waste & $\times$ & & & $x$ & & & & & \\
\hline Waste minimisation policy & $\times$ & $\times$ & $x$ & & & & $x$ & & \\
\hline $\begin{array}{l}\text { Land filled waste minimisation } \\
\text { policy }\end{array}$ & $x$ & & & & & $x$ & & & \\
\hline
\end{tabular}

Source: Airport operators' official web-sites [23-31]. 


\section{RESULTS OF THE ENVIRONMENTAL PLAN EVALUATION IN TEN EUROPEAN REGIONAL AIRPORTS}

The evaluation deals with several criteria and sub-criteria in airports' environmental plans. Following a systematic approach the key issues should be included in the environmental plans grouped in six main categories of criteria. In addition, for the purpose of the evaluation analysis these criteria include 34 sub-criteria, covering most environmental issues that have to be managed by airports. Table 9 summarises the criteria and the sub-criteria of the evaluation.

Table 10 presents the number of sub-criteria assessed in the environmental plan for the sample of ten European regional airports.

Table 8: Measures taken, regarding ecosystems, for 10 European regional airports.

\begin{tabular}{lllllllll}
\hline & \multicolumn{5}{c}{ Airports } \\
\cline { 2 - 6 } Measures regarding ecosystems & MAN NCL EMA BLQ & LEJ & IBZ & SXB & EIN RHO CFU \\
\hline $\begin{array}{l}\text { Protection of biodiversity, areas } \\
\text { and features of wildlife value or }\end{array}$ & $\times$ & $\times$ & $\times$ & & $\times$ & $\times$ & $\times$ & \\
$\begin{array}{l}\text { other ecological interest } \\
\text { Monitor fauna or/and flora }\end{array}$ & $\times$ & & & & & & & \\
\hline
\end{tabular}

Source: Airport operators' official web-sites [23-31].

Table 9: Criteria and sub-criteria of evaluation.

\begin{tabular}{ll}
\hline Noise & Water \\
1. noise action plan & 1. monitor water quality \\
2. noise reporting & 2. manage water runoffs \\
3. noise monitoring & 3. monitor water consumption \\
4. operating restrictions & 4. water conservation program \\
5. air traffic management & 5. use of rainwater, grey water or treated \\
6. land use planning & water \\
7. special infrastructure to buildings & 6. water saving devices \\
8. noise fee policy & 7. wastewater treatment \\
9. registration of noise complaints & Waste \\
Climate change & 1. recycling \\
1. climate change policy & 2. waste and recycling facilities \\
2. calculation of CO 2 emissions & 3. charges for contamination of recycling \\
3. energy efficiency & \multicolumn{1}{c}{ containers } \\
4. reduction of required energy & 4. calculation of the generated waste \\
5. renewable electricity & 5. waste minimisation policy \\
6. public transport & 6. land filled waste minimisation policy \\
7. use hybrid or electric vehicles & Ecosystems \\
Air quality & 1. protection of biodiversity \\
1. air quality monitoring & 2. monitor fauna or/and flora \\
2. air quality reporting/modelling &
\end{tabular}


Table 10: Mitigating measures included in the environmental plans of the selected airports.

\begin{tabular}{|c|c|c|c|c|c|c|c|c|c|c|c|}
\hline \multicolumn{2}{|c|}{ Evaluation criteria } & \multicolumn{10}{|c|}{$\begin{array}{c}\text { Number of sub-criteria covered in the selected airports' } \\
\text { environmental plans }\end{array}$} \\
\hline Description & $\begin{array}{l}\text { Sub- } \\
\text { criteria }\end{array}$ & MAN & NCL & EMA & BLQ & LEJ & IBZ & SXB & EIN & RHO & $\mathrm{CFU}$ \\
\hline Noise & 9 & 9 & 7 & 8 & 5 & 6 & 3 & 7 & 5 & 0 & 0 \\
\hline Climate change & 7 & 7 & 4 & 4 & 4 & 2 & 4 & 3 & 3 & 0 & 0 \\
\hline Air quality & 3 & 3 & 3 & 3 & 3 & 0 & 3 & 3 & 1 & 0 & 0 \\
\hline Water & 7 & 6 & 2 & 2 & 3 & 3 & 5 & 4 & 1 & 0 & 0 \\
\hline Waste & 6 & 6 & 2 & 3 & 2 & 0 & 2 & 2 & 2 & 0 & 0 \\
\hline Ecosystems & 2 & 2 & 2 & 1 & 0 & 1 & 1 & 1 & 0 & 0 & 0 \\
\hline Total & 34 & 33 & 20 & 21 & 17 & 12 & 18 & 20 & 12 & 0 & 0 \\
\hline
\end{tabular}

Additional findings of the environmental plan evaluation could be summarised as follows:

1. None of the 10 European regional airports meet all of the selected criteria of evaluation.

2. All airports recognise the need to specify an environmental management strategy to meet the national standards and the EU regulation framework.

3. Not many regional airports, especially the small ones, have set specific targets about their environmental performance. It seems that, the environmental strategy of the regional airports, whenever exists, depends on their location. Airports located in countries/states that have applied specific environmental policies appear to have set specific short, medium and longterm targets regarding noise, air quality, water resources, waste management, climate change and ecosystems. In addition, those airports were developed based on a sustainable and neutral airport development model focusing their strategy on reducing energy consumption and supply renewable energy.

4. Not many regional airports have introduced emission charging strategies, in order to optimise aircraft type and encourage low emission operation. This may have happened because most of the regional airports have focused on attracting new routes and stimulating demand to new destinations, rather than restrict existing operations.

5. Many airports in order to extend their activities apply special measures to increase the community's tolerance through modern techniques in air traffic management (e.g. route paths control), terminal operation, noise monitoring, landside noise barriers (e.g. charges for road use), special infrastructure to buildings, and public consultation with the stakeholders and the local communities.

6. Most of the airports initiatives focus on airside traffic and did not include the landside development and operation in the airport environmental planning process. This may happen because in most of them the landside area is controlled by the local authorities and the airport operator is not authorised to apply measures to control surface access and land use development.

7. Airports that serve more than 5 million passengers per year seem to have a more detailed environmental management strategy.

8. The majority of the regional airports in our sample seemed to have at least a written document under the title of environmental plan or strategy. However, only half of them have set specific targets. It is noteworthy that, airports operated by civil authorities, located in countries that do 
not have applied specific environmental policies, do not have any environmental plan or some notes about policies and targets to control environment disturbance.

9. The majority of the regional airports in our sample presented a noise action plan focused on methods and procedures for monitoring airport noise. Also, most of them have adopted operational restrictions and limitations for the noise control of the area surrounding them.

10. The majority of the regional airports in our sample had a climate change policy and took measures to reduce emissions. Most of them used renewable energy or energy ecologically generated.

11. The majority of the regional airports in our sample recycled their waste, but most of them did not have a complete waste management system.

12. The majority of the regional airports in our sample was controlling the discharges and monitors the water quality, but only some of them were trying to minimise their water consumption.

13. The majority of the regional airports in our sample published only general guidelines not specific measures or numerical data that can be easily standardised and used in an evaluation model. As a result, even a simple evaluation model about efficiency measures is difficult to be conducted.

14. Indices that could be used for the evaluation of the measures adopted by various environmental plans have to do with the nuisance of the locals (noise complaints, number of residents affected, movements allowed at night, etc.), energy used, carbon footprint, water consumption, recycling and waste management.

\section{CONCLUSIONS}

Across Europe there exist examples of airports that are unable to make full use of their capacity, as a result of the disturbance caused by aircraft noise and climate change. If regional airports development intents to add demand across European air transport network, strategic consideration regarding noise disturbance should be given.

This may not only require investment in noise control and mitigation strategies, but also require major investment in new infrastructure to shield local communities from ground noise or, in the case of the construction of a new runway, to enable arriving and departing aircraft to be flown away from noise sensitive communities and environmental sensitive locations. The economic implications of such an action could be significant but, in the context of sustainable development, such investment could be critical to ensure the ongoing growth of aviation, and thereby economic development at a particular location.

The results of the existing environmental plans analysis for a sample of 10 European regional airports present significant differences, mainly, due to the national legislation framework and resident's tolerance along with the airport business strategy, such as the management scheme and the accommodate traffic. If the airport industry wants to be in alignment with the sustainable development concept then it should give more attention to the regional airports' environmental management and provide the essential framework to enforce uniformity on both management systems and industry targets. The limited literature allowing a comparison of airports' environmental systems performance, leads us to call for more research in this area in the future.

\section{REFERENCES}

[1] International Civil Aviation Organization (ICAO), Growth in air traffic projected to continue to 2025, ICAO, RIO 08/2007, www.icao.int/icao/en/nr/2007/pio200708_e.pdf, accessed January 2009.

[2] Airports Council International (ACI), Creating employment and prosperity in Europe: a study of the social and economic impacts of airport, ACI Europe, 1998.

[3] Dimitriou, D., Daley, B. \& Thomas, C., Aviation and environment at tourism destinations: issues of sustainable development. Proceedings ATRS 2008, Paper 354, Athens, 2008. 
[4] Thomas, C. \& Lever, M., Aircraft noise, community relations and stakeholder involvement. Towards Sustainable Aviation, Earthscan: London, pp. 97-112, 2003.

[5] Caves, R., The social and economic benefits of aviation, Part 1. Towards Sustainable Aviation, Earthscan: London, pp. 36-47, 2003.

[6] Thomas, C., Dimitriou, D. \& Iatrou, K., Airports sustainable development: principles and key issues, ACI, Aviation dialogue, Issue 1, pp. 2-3, 2009.

[7] Upham, P., Thomas, C., Gillingwater, D. \& Raper, D., Environmental capacity and airport operations: current issues and future prospects. Journal of Air Transport Management, 9, pp. 145-151, 2003.

[8] European Commission, Networks for peace and development. Report from the High Level Group Chaired by Loyola de Palacio, European Commission (EC), pp. 26-27, 2005.

[9] ACI Europe, ACI Europe position on aviation and climate change, 2007, www.aci-europe.org, accessed July 2009.

[10] Daley, B., Dimitriou, D. \& Thomas, C., Chapter 18: The environmental sustainability of aviation and tourism. Aviation and Tourism, Ashgate: UK, pp. 239-253, 2008.

[11] Lee, D., Fahey, D., Forster, P., Newton, P., Wit, R., Lim, L., Owen, B. \& Sausen, R., Aviation and global climate change in the 21 st century. Atmospheric Environment, 43, pp. 3520-3537, 2009.

[12] Intergovernmental Panel on Climate Change (IPCC), IPCC Fourth Assessment Report: Climate Change 2007, accessed July 2009.

[13] Aviation Environment Federation (AEF), UK, www.aef.org.uk, accessed July 2009.

[14] Hooper, P., Aircraft noise. The Communication Challenge, Sustainable Aviation Short Course, 2009.

[15] Directive 2002/30/EC, http://eur-lex.europa.eu, accessed July 2009.

[16] Directive 2002/49/EC, http://eur-lex.europa.eu, accessed July 2009.

[17] Airport Carbon Accreditation, www.airportcarbonaccreditation.org, accessed July 2009.

[18] Meinshausen, M. \& Raper, S., The rising effect of aviation on climate. Omega Report, CATE, MMU, 2009.

[19] Airports Council International (ACI), Airport Benchmarking to Maximise Efficiency, ACI Europe, pp. 6-12, 2006.

[20] Transport Research Laboratory (TRL), Airport Performance Indicators, pp. 6-10, 2004.

[21] Air Transport Research Society (ATRS), Airport Benchmarking Report: Global Standards for Airport Excellence, pp. 4-14, 2007.

[22] ACI Europe, Airport Awards, www.aci-europe-events.com/annual-general-assembly/awards, accessed July 2009.

[23] East Midlands Airport, www.eastmidlandsairport.com, accessed July 2009.

[24] Eindhoven Airport, www.eindhovenairport.com, accessed July 2009.

[25] Environmental Plan of Manchester Airport, Manchester Airport Master Plan to 2030, 2005.

[26] Hellenic Civil Aviation Authority, www.ypa.gr, accessed July 2009.

[27] Ibiza Airport, www.aena.es, accessed July 2009.

[28] Leipzig Halle Airport, www.leipzig-halle-airport.de, accessed July 2009.

[29] Newcastle International Airport Noise Action Plan (draft for consultation), 2009.

[30] Strasbourg International Airport, www.strasbourg.aeroport.fr, accessed July 2009.

[31] Sustainability report of Aeroporto 'G. Marcoli' di Bologna, 2007.

[32] ACIEurope, General Assembly. Annual Congress and Exhibition, Airports Council International Europe, 18-20 June 2008, Paris, France, Air Transport News, htpp://www.airtransportnews/ reports, accessed June 2008. 